\title{
Do posture correction exercises have to be boring? Using unstable surfaces to prevent poor posture in children
}

\section{Czy gimnastyka korekcyjna musi być nudna? Wykorzystanie powierzchni niestabilnych w profilaktyce wad postawy u dzieci}

\author{
Agnieszka Jankowicz-Szymanskaํ․, Edyta Mikolajczyk² \\ ${ }^{1}$ Institute of Health Sciences, State Higher Vocational School, Tarnow, Poland \\ Head of the Institute: Mariusz Pociecha PhD \\ 2Department of Physiotherapy, University of Physical Education, Krakow, Poland \\ Head of the Department: Prof. Anna Marchewka PhD
}

Key words: body posture, faulty posture, unstable surfaces, children.

Słowa kluczowe: postawa ciała, wady postawy, powierzchnia niestabilna, dzieci.

\begin{abstract}
Introduction: Poor posture in children is a common problem. It appears most often in early school-age children and, if not corrected, progresses quickly as they mature.

Aim of the research: To find a method that can prevent poor posture, is effective and attractive for children, and can be used on a wide scale in state schools.

Material and methods: Seventy-seven first year pupils were tested at the beginning and at the end of the school year. Nineteen children undertook corrective exercises using unstable surfaces; 41 children sat on sensorimotor pillows during classes; and 17 children were the control group. Body mass and body height were measured. Body mass index was calculated. The symmetry of the position of selected skeletal points was assessed: the acromions, lower angles of the scapulas, apexes of the iliac crests, antero-superior iliac spine, and postero-superior iliac spine using a Duometer electronic device. The differences between the groups and changes between the first and second study for each group were estimated.

Results: In the first study there were no significant differences in quality of posture. In the second study a significant improvement was noted in symmetry of the shoulders, scapulas, and pelvis in children who sat on sensorimotor pillows, as well as the position of the iliac crests and iliac spines in children exercising regularly on unstable surfaces.

Conclusions: Exercises using unstable surfaces and sitting on sensorimotor pillows during classes might be an effective alternative to traditional posture correction exercises.
\end{abstract}

\section{Streszczenie}

Wprowadzenie: Wady postawy u dzieci są powszechnym problemem. Pojawiają się najczęściej we wczesnym wieku szkolnym i - niekorygowane - szybko postępują w okresie dojrzewania.

Cel pracy: Znalezienie metody zapobiegania wadom postawy, która byłaby efektywna, atrakcyjna dla dzieci i możliwa do szerokiego zastosowania w szkołach.

Materiał i metody: Na początku (wrzesień) i pod koniec (czerwiec) roku szkolnego zostało przebadanych 77 uczniów. Spośród nich 19 dwa razy w tygodniu wykonywało ćwiczenia korekcyjne na powierzchniach niestabilnych, 41 dzieci siedziało podczas lekcji na poduszkach sensomotorycznych, a 17 dzieci stanowiło grupę kontrolną. Zmierzono masę i wysokość ciała. Obliczono wskaźnik masy ciała. Oszacowano symetrię położenia wybranych punktów anatomicznych: wyrostków barkowych łopatki, kątów dolnych łopatki, szczytów talerzy biodrowych, kolców biodrowych przednich górnych i tylnych górnych. Wykorzystano elektroniczny Duometr. Oszacowano różnice międzygrupowe i zmiany, jakie zaszły w postawie ciała u uczniów w każdej z grup pomiędzy pierwszym i drugim badaniem.

Wyniki: $\mathrm{W}$ pierwszym badaniu nie dostrzeżono istotnych różnic międzygrupowych $\mathrm{w}$ jakości postawy ciała. W drugim badaniu odnotowano istotną poprawę ustawienia barków, łopatek i miednicy u dzieci, które siedziały na poduszkach sensomotorycznych, oraz poprawę ustawienia talerzy i kolców biodrowych u dzieci ćwiczących systematycznie na powierzchniach niestabilnych.

Wnioski: Ćwiczenia z zastosowaniem powierzchni niestabilnych i siedzenie na poduszkach sensomotorycznych podczas lekcji mogą stanowić skuteczną alternatywę dla tradycyjnej gimnastyki korekcyjnej. 


\section{Introduction}

For children, beginning school changes their life style to a great degree. School education requires sitting for several hours every day. During standard classes, pupils are sitting for $97 \%$ of the time, $1 / 3$ of which they are leaning forward, reading or writing [1]. The dimensions of school furniture are not usually suited to children's bodies, which make it more difficult for them to maintain a correct seated position $[2,3]$. Outside school, children also spend a lot of time sitting, mainly in front of the television or using a computer $[4,5]$. School bags are often too heavy or inappropriately carried [6, 7], which leads to the deterioration of body posture [8] or back pain $[9,10]$. The overall effect is the universal deterioration of body posture in the early schooling years [11-14].

\section{Aim of the research}

The aim of the study was to find an effective method to prevent body posture defects in children beginning school education. The intention of the authors was to create a programme that satisfies the following criteria: high effectiveness, low economic costs, an attractive programme for children, and one that can be carried out during the period that the child is at school, without the necessity of the involvement of the parents and children during their free time.

\section{Material and methods}

Seven-year-old children beginning primary education were observed. These children were from four groups in the same school. Pupils were excluded from the study if they had a history of musculoskeletal disorder or pain. In the final analysis, the results for 77 children ( 35 girls and 42 boys) were taken into consideration. The parents or legal guardians gave written consent for the involvement of the children in the study. The agreement of the local bioethics committee (approval number 2/0177, Ethics Committees at the Regional Medical Chamber) was also obtained.

The study was conducted twice: in September 2012 and in June 2013, at the beginning and end of the school year. The children were tested individually in a nurse's room, dressed in underwear. Body mass was measured to a precision of $0.1 \mathrm{~kg}$ on a Tanita scale. Height was measured to a precision of $0.01 \mathrm{~m}$ on a calibrated Martin type anthropometer. To measure height, children stood bare-footed, feet together, in a straight posture, eyes forward. The results were written down on a designated study form. Body mass index (BMI) was calculated on the basis of these data.

On a Technomex Alfa balance board the right and left lower limb loading in a habitual standing position were studied. The results were given as a percentage of body mass. The symmetry of the position of selected skeletal points was assessed: the acromions, lower angles of the scapulas, apexes of the iliac crests, antero-superior iliac spine, and postero-superior iliac spine. Using a Duometer electronic device, the deviation of specific anatomic points of the left and right side of the body from the horizontal level was established. The results were presented according to gradation. All the children were examined by the same experienced physiotherapist, who did not know which group the child was assigned to in the study.

The procedure was as follows: A group was randomly selected (19 children) and called SE (sensorimotor exercises). Pupils from this group undertook 15-minute exercises twice a week for the whole school year, which developed correct posture using unstable surfaces: Swiss balls and sensorimotor discs. These exercises were included as part of (physical education) PE classes in the gymnastics hall. The children were dressed in sportswear.

Example exercises: standing with both feet on the disc, eyes open; standing with both feet on the disc, eyes closed; standing with one foot on the disc, arms spread out; doing squats standing with both feet on the disc; sitting cross-legged on the disc, palms on knees, leaning forwards and returning to starting position; kneeling on all-fours, palms and knees on the disc, raising both the right hand and left leg to the horizontal position, returning to the starting position, alternating limbs; sitting on a ball, back straight, eyes forward, palms on knees, balancing the hips, right and left sides; sitting on the ball, arms spread out rotating outwards, lifting the feet off the surface, attempting to maintain balance; sitting on a ball, abdominal muscles tensed stabilising the pelvis, arms up, side bends to the left and right; attempting to maintain balance in a front lying position on a ball (exercise performed with supervision). The teacher paid special attention to the correctness of the exercises performed.

Pupils from another two groups (41 children), specified as the SP group (sensorimotor pillows), sat on sensorimotor pillows placed on standard chairs during classes. Children were not taught how to sit. They did not sit on a sensorimotor pillow at home. The children did not perform any additional exercises for correcting posture. A third group (17 people), called the control group (C), consisted of children who sat on standard chairs during classes, and did not perform exercises on non-stable surfaces or other exercises to correct their posture. During PE class the $\mathrm{C}$ and SP groups performed general developmental exercises as well as motor activities and games. Pupils from all groups did not participate in additional exercises or trainings.

When the children started primary school (first study) the average body mass of all those studied was $24.62 \mathrm{~kg}$ and was similar in all groups (Table 1). The average height of all studies was $123.71 \mathrm{~cm}$ and the BMI was $16.01 \mathrm{~kg} / \mathrm{m}^{2}$. Over 10 months of the school year 
Table 1. Somatic features, the lower limbs loading, and trunk setting in the frontal plane in the study groups at the beginning and end of the experiment (Repeated measures ANOVA, $\alpha=0.05$ )

\begin{tabular}{|c|c|c|c|c|}
\hline \multirow[t]{2}{*}{ Variable } & \multirow[t]{2}{*}{ Group } & \multicolumn{2}{|c|}{ Mean \pm SD } & \multirow[t]{2}{*}{$P$-value } \\
\hline & & Sept. 2012 & June 2013 & \\
\hline \multirow[t]{3}{*}{ Body weight [kg] } & SE & $24.83 \pm 5.42$ & $27.22 \pm 6.53$ & 0.1702 \\
\hline & SP & $24.51 \pm 4.40$ & $27.39 \pm 6.34$ & $0.0287^{*}$ \\
\hline & $\mathrm{C}$ & $24.16 \pm 4.98$ & $27.25 \pm 5.67$ & 0.3414 \\
\hline \multirow[t]{3}{*}{ Body height [cm] } & SE & $125.11 \pm 4.67$ & $128.98 \pm 5.56$ & 0.0690 \\
\hline & SP & $123.31 \pm 5.14$ & $127.22 \pm 5.84$ & 0.0724 \\
\hline & C & $121.50 \pm 4.35$ & $125.66 \pm 5.17$ & 0.0632 \\
\hline \multirow[t]{3}{*}{ BMI [kg/m²] } & SE & $15.77 \pm 2.57$ & $16.23 \pm 2.82$ & 0.4824 \\
\hline & SP & $16.04 \pm 2.19$ & $16.79 \pm 2.78$ & 0.3785 \\
\hline & C & $16.33 \pm 2.68$ & $17.10 \pm 2.44$ & 0.8147 \\
\hline \multirow[t]{3}{*}{ Right leg loading (\%) } & SE & $50.61 \pm 2.30$ & $50.35 \pm 1.49$ & 0.9506 \\
\hline & SP & $49.78 \pm 2.05$ & $50.64 \pm 1.98$ & 0.9891 \\
\hline & C & $50.83 \pm 2.75$ & $50.91 \pm 1.67$ & 0.9302 \\
\hline \multirow[t]{3}{*}{ Left leg loading (\%) } & SE & $49.38 \pm 2.29$ & $49.65 \pm 1.49$ & 0.9526 \\
\hline & SP & $50.21 \pm 2.05$ & $49.35 \pm 1.98$ & 0.1025 \\
\hline & C & $49.16 \pm 2.75$ & $49.08 \pm 1.67$ & 0.9324 \\
\hline \multirow[t]{3}{*}{ Difference between right and left leg loading (\%) } & SE & $3.44 \pm 3.20$ & $2.28 \pm 1.97$ & 0.5780 \\
\hline & $\mathrm{SP}$ & $3.26 \pm 2.47$ & $3.24 \pm 2.59$ & 0.9861 \\
\hline & $\mathrm{C}$ & $4.33 \pm 3.60$ & $3.16 \pm 1.99$ & 0.1844 \\
\hline \multirow[t]{3}{*}{ Difference between the acromions position $\left[^{\circ}\right]$} & SE & $1.31 \pm 1.22$ & $0.70 \pm 0.83$ & 0.9342 \\
\hline & SP & $2.17 \pm 1.59$ & $0.79 \pm 0.97$ & $0.0001^{*}$ \\
\hline & $\mathrm{C}$ & $1.75 \pm 1.25$ & $1.70 \pm 1.33$ & 0.1599 \\
\hline \multirow[t]{3}{*}{ Difference between the scapulas position $\left[^{\circ}\right]$} & SE & $1.26 \pm 1.25$ & $0.67 \pm 1.08$ & 0.9321 \\
\hline & $\mathrm{SP}$ & $1.89 \pm 1.39$ & $0.85 \pm 1.61$ & $0.0042^{*}$ \\
\hline & C & $1.78 \pm 2.01$ & $1.71 \pm 1.74$ & 0.1420 \\
\hline \multirow{3}{*}{$\begin{array}{l}\text { Difference between right and left iliac crest } \\
\text { position }\left[^{\circ}\right]\end{array}$} & SE & $1.26 \pm 1.21$ & $0.49 \pm 0.85$ & 0.5332 \\
\hline & SP & $1.26 \pm 1.13$ & $0.24 \pm 0.70$ & $0.0001^{*}$ \\
\hline & $\mathrm{C}$ & $0.61 \pm 0.64$ & $0.86 \pm 1.10$ & $0.0361^{*}$ \\
\hline \multirow{3}{*}{$\begin{array}{l}\text { Difference between right and left antero-superior } \\
\text { iliac spine position [ }{ }^{\circ} \text { ] }\end{array}$} & SE & $1.17 \pm 1.14$ & $0.33 \pm 0.72$ & $0.0092^{*}$ \\
\hline & SP & $1.16 \pm 0.85$ & $0.18 \pm 0.25$ & $0.0001^{*}$ \\
\hline & $C$ & $0.97 \pm 0.91$ & $0.89 \pm 1.14$ & 0.8354 \\
\hline \multirow{3}{*}{$\begin{array}{l}\text { Difference between right and left postero- } \\
\left.\text { superior iliac spine position [ }{ }^{\circ}\right]\end{array}$} & SE & $1.21 \pm 1.23$ & $0.28 \pm 0.56$ & $0.0033^{*}$ \\
\hline & SP & $0.88 \pm 0.77$ & $0.06 \pm 0.26$ & $0.0001^{*}$ \\
\hline & $C$ & $0.92 \pm 0.75$ & $0.48 \pm 0.68$ & 0.1221 \\
\hline
\end{tabular}

*Statistically significant differences. 
the children increased their body mass by $2.38 \mathrm{~kg}$ height by $3.87 \mathrm{~cm}$, and BMI by $0.48 \mathrm{~kg} / \mathrm{m}^{2}$. The only statistically significant change concerned the body mass of the SP group.

\section{Statistical analysis}

In the analysis the average and standard deviation were used to describe the changes, the Shapiro-Wilk test was used to analyse the normality of the distribution, the factorial ANOVA and post-hoc Tukey test to compare intergroup, and repeated measures ANOVA to specify the significance of differences between the first and second study. The differences were found to be significant at $p<0.05$.

\section{Results}

In the first study it was stated that the children from the SE and C groups had greater right than left leg loading in the standing position, whereas the children from the SP group had greater left leg loading. In the second study, a greater loading in the right leg was noted in all three groups. The most significant difference in the loading in the right and left leg due to body weight was observed in the first study of $\mathrm{C}$ group and in the second study of SP group. The most symmetrical loading on the right and left legs in the standing position was shown in the first study in the SP group and in the second study in the SE group.

By assessing the trunk setting, the deviation of the linking line of selected skeletal points of the right and left sides relative to the horizontal was established. In the first study the greatest asymmetries were noted for the placement of the acromions and lower angles of the scapulas in the SP group, the iliac crests in the SE and SP groups, and antro-superior iliac spine and postero-superior iliac spine in the SE group. In this same study the most symmetrical position of the acromions and scapulas were noted in the SE group, iliac crests and antero-superior iliac spine in the $\mathrm{C}$ group, and postero-superior iliac in the SP group.

Comparing the first and second studies, a more significant symmetrical position of all studied anthropometric points was noted in the SP group. The significant differences also concerned the antero-superior and postero-superior iliac spines in the SE group (greater symmetrical positioning) and iliac crests in the $\mathrm{C}$ group (greater asymmetry in the second study compared with the first study).

Somatic features (body mass, height, and BMI) did not differentiate the studied groups (Table 2). Neither in the first nor the second study were significant differences in loading in the right and left leg noted. Whereas a significant difference was noted in the placement of the acromions between the $\mathrm{C}$ and SE groups in the second study and the the placement of the postero-superior iliac spine between $\mathrm{C}$ and SP groups as well as C and SE groups in the second study.

\section{Discussion}

Faults in body posture are diagnosed in a significant percentage of children of early school age. A preventative programme of systematic exercises on non-stable surfaces and sitting on a sensorimotor disc during school lessons corrected trunk setting in the frontal plane. In creating the programme, the authors decided to use Swiss balls and sensorimotor discs because of the widely held opinion that exercises on non-stable surfaces have a beneficial influence on stimulating proprioception and core stability [15]. Using non-stable surfaces improves the reaction speed of the muscles, increasing motor control and activating preferred motor strategies [16, 17].

Wit [18] noted the positive effects of using Swiss balls instead of chairs in school classrooms. Pupils noticed an improvement in body posture and increase of muscle strength in themselves. Schilling et al. [19] successfully used sitting on Swiss balls during classes as a supplementary therapy for children with ADHD. The authors' own experience suggests that non-stable surfaces also work well in making people with intellectual disabilities more effective [20,21]. Children like and willingly perform exercises on balls and discs.

In most schools, tables and chairs are of standard height. They are not suited to the pupils' bodies. Children often use different classrooms and do not have designated places to work. An asymmetrical sitting position, with an excessively curved back and head forward is typical for pupils [22, 23]. This sitting position is similar in children using tablets or drawing [24]. A careless sitting position is associated with the increasingly observed back pain and headaches in children [25-29]. Learning the appropriate sitting position serves not only posture defect prevention but also counteracts neck and back pain [30].

In these studies, sensorimotor discs placed on chairs were used to stimulate correct sitting position. This choice was for practical reasons. Children moving between classrooms carried with themselves this small, light disc. This was much more convenient than taking a huge ball or chair to their next classroom. Introducing exercises on non-stable surfaces in the PE programme for another group of children resulted from the assumption that correct posture should be maintained all the time, not only while seated. This is why children were doing both static as well as dynamic exercises in various starting positions. It is assumed that training on non-stable surfaces makes them maintain a balanced position, which are optimal when the trunk is set properly [31].

The results show that both systematically performed exercises and sitting in classrooms on sensorimotor pillows serves the symmetrical setting of the shoulder girdle and pelvis. A more notable effect (confirmed by statistical significance) was observed in 
Table 2. Intergroup differences in the level of somatic features, the lower limbs loading, and trunk setting (Factorial ANOVA and post-hoc Tukey test, $\alpha=0.05$ )

\begin{tabular}{|c|c|c|c|}
\hline \multirow[t]{2}{*}{ Variable } & \multirow[t]{2}{*}{ Groups } & \multicolumn{2}{|c|}{$P$-value } \\
\hline & & Sept. 2012 & June 2013 \\
\hline \multirow[t]{3}{*}{ Body weight } & $C \& S P$ & 0.9945 & 0.9999 \\
\hline & $C \& S E$ & 0.9121 & 0.9878 \\
\hline & SP \& SE & 0.9207 & 0.9995 \\
\hline \multirow[t]{3}{*}{ Body height } & $C \& S P$ & 0.9657 & 0.8458 \\
\hline & $C \& S E$ & 0.2362 & 0.2120 \\
\hline & SP \& SE & 0.3001 & 0.4457 \\
\hline \multirow[t]{3}{*}{ BMI } & $C \& S P$ & 0.9999 & 0.9772 \\
\hline & $C \& S E$ & 0.8966 & 0.6722 \\
\hline & SP \& SE & 0.9155 & 0.7901 \\
\hline \multirow[t]{3}{*}{ Right leg loading } & $C \& S P$ & 0.2375 & 0.6138 \\
\hline & $C \& S E$ & 0.8224 & 0.6777 \\
\hline & SP \& SE & 0.5197 & 0.9999 \\
\hline \multirow[t]{3}{*}{ Left leg loading } & $C \& S P$ & 0.2334 & 0.6114 \\
\hline & $C \& S E$ & 0.8244 & 0.6736 \\
\hline & SP \& SE & 0.5100 & 0.9988 \\
\hline \multirow{3}{*}{$\begin{array}{l}\text { Difference between right and left leg } \\
\text { loading }\end{array}$} & $C \& S P$ & 0.3468 & 0.7301 \\
\hline & C \& SE & 0.3825 & 0.1633 \\
\hline & SP \& SE & 0.9982 & 0.4800 \\
\hline \multirow{3}{*}{$\begin{array}{l}\text { Difference between the acromions } \\
\text { position }\end{array}$} & $C \& S P$ & 0.6501 & 0.0499 \\
\hline & $C \& S E$ & 0.6850 & $0.0152^{*}$ \\
\hline & SP \& SE & 0.1788 & 0.8774 \\
\hline \multirow[t]{3}{*}{ Difference between the scapulas position } & $C \& S P$ & 0.9393 & 0.3222 \\
\hline & $C \& S E$ & 0.8007 & 0.2005 \\
\hline & SP \& SE & 0.5568 & 0.9572 \\
\hline \multirow{3}{*}{$\begin{array}{l}\text { Difference between right and left iliac } \\
\text { crest position }\end{array}$} & $C \& S P$ & 0.1909 & 0.1774 \\
\hline & $C \& S E$ & 0.2026 & 0.5700 \\
\hline & SP \& SE & 0.9999 & 0.6737 \\
\hline \multirow{3}{*}{$\begin{array}{l}\text { Difference between right and left antero- } \\
\text { superior iliac spine position }\end{array}$} & C \& SP & 0.9958 & 0.0521 \\
\hline & C \& SE & 0.6600 & 0.2899 \\
\hline & SP \& SE & 0.5416 & 0.6301 \\
\hline \multirow{3}{*}{$\begin{array}{l}\text { Difference between right and left postero- } \\
\text { superior iliac spine position }\end{array}$} & $C \& S P$ & 0.8251 & $0.0134^{\star}$ \\
\hline & $C \& S E$ & 0.6776 & $0.0311^{\star}$ \\
\hline & SP \& SE & 0.9658 & 0.9016 \\
\hline
\end{tabular}

*Statistically significant differences. 
the SP group. Perhaps an increased frequency of exercises would have been required. These studies were restricted to assessing the trunk setting in the frontal plane. The authors intend to repeat the experiment with another first-year group, broadened to threedimensional assessment of posture using different research tools. The observation of children's posture discussed in this study will also be continued.

\section{Conclusions}

Regular exercises on non-stable surfaces, as well as sitting on sensorimotor discs during classes, improves body symmetry in the frontal plane. The proposed exercise programme presented that using sensorimotor discs and Swiss balls as well as sitting on sensorimotor discs might be an effective preventative method for early school age children with poor posture.

\section{Conflict of interest}

The authors declare no conflict of interest.

\section{References}

1. Cardon G, De Clercq D, De Bourdeaudhuij I, Breithecker D. Sitting habits in elementary schoolchildren: a traditional versus a "Moving school". Patient Educ Couns 2004; 54: 133-42.

2. Panagiotopoulou G, Christoulas K, Papanckolaou A, Mandroukas K. Classroom furniture anthropometric measures dimensions and in primary school. Appl Ergon 2004; 35: 121-8.

3. Gouvali MK, Boudolos K. Match between school furniture dimensions and children's anthropometry. Appl Ergon 2006; 37: 765-73.

4. Smpokos EA, Linardakis M, Papadaki A, Lionis C, Kafatos A. Secular trends in fitness, moderate-to-vigorous physical activity, and TV-viewing among first grade school children of Crete, Greece between 1992/93 and 2006/07. J Sci Med Sport 2012; 15: 129-35.

5. Rideout V, Foehr U, Roberts D. Generation M2: media in the lives of 8- to 18-year-olds. The Henry J. Kaiser Family Foundation: Menlo Park, CA; 2010.

6. Kistner F, Fiebert I, Roach K, Moore J. Postural compensations and subjective complaints due to backpack loads and wear time in schoolchildren. Pediatr Phys Ther 2013; 25: 15-24.

7. Barkhordari A, Ehrampoush MH, Barkhordari M, Derakhshi F, Barkhoradri M, Mirzaii M. Assessment of school backpack weight and other characteristics in elementary schools, Yazd-Iran. J Health Res 2013; 2: 2-7

8. Rai A, Agarwal S, Bharti S. Postural effect of back packs on school children: its consequences on their body posture. Int J Health Sci Res 2013; 3: 109-16.

9. Watson KD, Papageorgiou AC, Jones GT, Taylor S, Symmons DP, Silman AJ, Macfarlane GJ. Low back pain in schoolchildren: occurrence and characteristics. Pain 2002; 97: 87-92.

10. Ramprasad M, Alias J, Raghuveer AK. Effect of backpack weight on postural angles in preadolescent children. Indian Pediatr 2010; 47: 575-80.
11. Chrimik K, Rohan-Fugiel A, Sliwa D, Fugiel J. Frequency of the occurrence of the body posture types among boys and girls at young school age. Acta Biooptica Inf Med 2009; 4: 346-7.

12. Lichota M. Change the shape of the anterior-posterior curvature of the spine in children aged 6-7 years. Phys Educ Sport 2008; 52: 13-6 [in Polish].

13. Kratenová J, Zejglicová K, Malý M, Filipová V. Prevalence and risk factors of poor posture in school children in the Czech Republic. J Sch Health 2007; 77: 131-7.

14. Drzał-Grabiec J, Snela S, Bibrowicz K. Body position in peroneal plane in children from Ist to IIIrd grades of elementary school. Przeg Med Uniw Rzesz 2009; 4: 363-6.

15. Stanton R, Reaburn PR, Humphries B. The effect of short-term Swiss ball training on core stability and running economy. J Strength Cond Res 2004; 18: 522-8.

16. Vera-Garcia FJ, Grenier SG, McGill SM. Abdominal muscle response during curl-ups on both stable and labile surfaces. Phys Ther 2000; 80: 564-9.

17. Haynes W. Core stability and the unstable platform device. J Bodyw Mov Ther 2004; 8: 88-103.

18. Witt LN. Use of the stability ball as a chair in the classroom. Tavelli Elementary School; Poudre School District 2001.

19. Schilling DL, Washington K, Billingsley FF, Deitz J. Classroom seating for children with attention deficit hyperactivity disorder: Therapy balls versus chairs. Am J Occup Ther 2003; 57: 534-41.

20. Jankowicz-Szymanska A, Mikolajczyk E, Wojtanowski W. The effect of physical training on static balance in young people with intellectual disability. Res Dev Disabil 2012; 33: 675-81.

21. Mikołajczyk E, Jankowicz-Szymańska A. The effect of unstable-surface functional exercises on static balance in adolescents with intellectual disability - a preliminary report. Medical Studies 2014; 30: 1-5.

22. Saarni L, Nygård CH, Kaukiainen A, Rimpelä A. Are the desks and chairs at school appropriate? Ergonomics 2007; 50: 1561-70.

23. Penha PJ, João SM, Casarotto RA, Amino CJ, Penteado DC. Postural assessment of girls between 7 and 10 years of age. Clinics 2005; 60: 9-16.

24. Straker LM, Coleman J, Skoss R, Maslen BA, Burgess-Limerick R, Pollock CM. A comparison of posture and muscle activity during tablet computer, desktop computer and paper use by young children. Ergonomics 2008; 51: 540-55.

25. Geldhof E, De Clercq D, De Bourdeaudhuij I, Cardon G. Classroom postures of 8-12 year old children. Ergonomics 20078; 50: 1571-81.

26. Trigueiro MJ, Massada L, Garganta R. Back pain in Portuguese schoolchildren: prevalence and risk factors. Eur J Pub Health 2013; 23: 499-503.

27. Cardon G, Balague F. Low back pain prevention's effects in schoolchildren. What is the evidence? Eur Spine J 2004; 13: 663-79.

28. Szpalski M, Gunzburg R, Balague F, Nordin M, Melot C. A 2-year prospective longitudinal study on low back pain in primary school children. Eur Spine J 2002; 11: 459-64.

29. Calvo-Muñoz I, Gómez-Conesa A, Sánchez-Meca J. Prevalence of low back pain in children and adolescents: a metaanalysis. BMC Pediatrics 2013; 13: 14. 
30. Koskelo R, Vuorikari K, Hanninen O. Sitting and standing postures are corrected by adjustable furniture with lowered muscle tension in high-school students. Ergonomics 2007; 50: 1643-56.

31. Stepien A, Seyfried A, Krawczyk M, Graff K. The impact of spinal deformity on feet load during gait in scoliosis subject. Adv Rehabil 2007; 2: 13-20.

\section{Address for correspondence:}

Agnieszka Jankowicz-Szymanska

Institute of Health Sciences

State Higher Vocational School

ul. A. Mickiewicza 8, 33-100 Tarnow, Poland

Phone: +48504238 962

Fax: +48 146316600

E-mail: jankowiczszymanska@gmail.com 